Technical Note

\title{
Phytoextraction of heavy metal polluted soils using Sedum plumbizincicola inoculated with metal mobilizing Phyllobacterium myrsinacearum RC6b
}

\author{
Ying Ma ${ }^{\mathrm{a}, \mathrm{b}, *}$, Mani Rajkumar ${ }^{\mathrm{c}}$, Yongming Luo ${ }^{\mathrm{d}, *}$, Helena Freitas ${ }^{\mathrm{a}}$ \\ ${ }^{a}$ Centre for Functional Ecology, Department of Life Sciences, University of Coimbra, Coimbra 3001-401, Portugal \\ ${ }^{\mathrm{b}}$ Key Laboratory of Soil Environment and Pollution Remediation, Institute of Soil Science, Chinese Academy of Sciences, Nanjing 210008, China \\ ${ }^{\mathrm{c}}$ National Environmental Engineering Research Institute (NEERI), CSIR Complex, Taramani, Chennai 600 113, India \\ ${ }^{\mathrm{d}}$ Yantai Institute of Coastal Zone Research, Chinese Academy of Sciences, Yantai, Shandong 264003, China
}

\section{H I G H L I G H T S}

- Isolated Phyllobacterium myrsinacearum RC6b effectively mobilized metals in soils.

- RC6b inoculation enhanced growth and Cd and Zn uptake of Sedum plumbizincicola.

- Possible mechanisms are plant beneficial activities and soil metal mobilization.

- RC6b is a good candidate for microbially assisted phytoremediation.

\section{A R T I C L E I N F O}

\section{Article history:}

Received 15 April 2013

Received in revised form 24 June 2013

Accepted 25 June 2013

Available online 23 July 2013

\section{Keywords:}

Phytoremediation

Cadmium

Plant growth-promoting rhizobacterium

Lead

Phyllobacterium myrsinacearum

Sedum plumbizincicola

\begin{abstract}
A B S T R A C T
The aim of this study was to investigate the effects of metal mobilizing plant-growth beneficial bacterium Phyllobacterium myrsinacearum RC6b on plant growth and $\mathrm{Cd}, \mathrm{Zn}$ and $\mathrm{Pb}$ uptake by Sedum plumbizincicola under laboratory conditions. Among a collection of metal-resistant bacteria, P. myrsinacearum RC6b was specifically chosen as a most favorable metal mobilizer based on its capability of mobilizing high concentrations of $\mathrm{Cd}, \mathrm{Zn}$ and $\mathrm{Pb}$ in soils. P. myrsinacearum RC6b exhibited a high degree of resistance to $\mathrm{Cd}$ (350 $\left.\mathrm{mg} \mathrm{L}^{-1}\right)$, Zn (1000 $\left.\mathrm{mg} \mathrm{L}^{-1}\right)$ and $\mathrm{Pb}\left(1200 \mathrm{mg} \mathrm{L}^{-1}\right)$. Furthermore, $P$. myrsinacearum RC6b showed multiple plant growth beneficial features including the production of 1-aminocyclopropane-1-carboxylic acid deaminase, indole-3-acetic acid, siderophore and solubilization of insoluble phosphate. Inoculation of $P$. myrsinacearum RC6b significantly increased S. plumbizincicola growth and organ metal concentrations except $\mathrm{Pb}$, which concentration was lower in root and stem of inoculated plants. The results suggest that the metal mobilizing P. myrsinacearum RC6b could be used as an effective inoculant for the improvement of phytoremediation in multi-metal polluted soils.
\end{abstract}

(c) 2013 Elsevier Ltd. All rights reserved.

\section{Introduction}

Contamination of soils with toxic heavy metals through mining operations, discharge of industrial effluents, extensive use of pesticides, fertilizers, etc., is of great concern due to its detrimental effects on soil biological systems (Giller et al., 1998). In China, thousands of abandoned or operating metal based ore mines exist on public lands, which have generated around 1500000 ha of metal polluted soil and increases at a rate of 46700 ha $^{-1}$ (MEPPRC, 2006). Results from recent studies (Kachenko and Singh, 2006; Zhuang et al., 2009) also demonstrate thatthe food crops grown

\footnotetext{
* Corresponding authors. Address: Centre for Functional Ecology, Department of Life Sciences, University of Coimbra, Coimbra 3001-401, Portugal. Tel.: +351 239 855210; fax: +351239855211 (Y. Ma).
}

E-mail addresses: cathymaying@gmail.com (Y. Ma), ymluo@yic.ac.cn (Y. Luo). in metal contaminated soils pose a major health concern. For instance, Li et al. (2006) reported that Chinese cabbage and Brassica napus grown in the vicinity of a Chinese $\mathrm{Pb} / \mathrm{Zn}$ mine had higher levels of heavy metals than the maximum permissible value in food proposed by food regulation. Thus, the development of effective remediation strategies for metal polluted soils that do not affect soil biological and ecological health is necessary. Conventional remediation methods such as soil washing and excavation, landfilling of the top contaminated soils, electrokinetic treatment, leaching and immobilization are expensive, time consuming and often harmful to soil biological system. Phytoremediation is a low cost and environmentally friendly technology, which uses plants and their associated microbes for inactivation or removal pollutants from the soil, water, sediments and air (Glick, 2003).

Although numerous plant species are capable of hyperaccumulating specific heavy metal, these plants are not suitable for 
treating soils contaminated with multiple metals because of their slow growth, low tolerance to multiple metal stress and inability to uptake multiple metals (Ghosh et al., 2011). Recently, microbial mediated plant stress amelioration has emerged as an important component of metal stress management in plants and their role in improving plant growth and phytoremediation process in metal polluted soils has been well established (Rajkumar et al., 2013). It has been demonstrated that the inoculation of plants with metalresistant plant growth-promoting rhizobacteria (PGPR) play an important role in improving the efficiency of heavy metal phytoremediation (Ma et al., 2011; Rajkumar et al., 2012). PGPR such as Azospirillum, Azotobacter, Achromobacter, Bacillus, Burkholderia, Gluconacetobacter, Pseudomonas and Serratia, have been known to improve plant growth through various mechanisms like production of phytohormones, siderophores and 1-aminocyclopropane1-carboxylic acid (ACC) deaminase, and solubilization of mineral nutrients (Rajkumar et al., 2008; Sheng et al., 2008; Ma et al., 2009).

Several factors including soil nutrients, $\mathrm{pH}$, plant type, their associated microbial flora, etc., affect plant-microbe interactions and thereby influence heavy metal uptake by plants. However, the bioavailability of heavy metals in rhizosphere soils is considered to be an important factor that determines the efficiency of phytoextraction process. Metal tolerant microbes have been frequently reported in the rhizosphere of hyperaccumulators growing in metal polluted soils indicating that these microbes have evolved a heavy metal-tolerance and that they may play significant roles in mobilization or immobilization of heavy metals by excreting various metabolites including organic acids or extracellular polymeric substances (Rajkumar et al., 2012; Prapagdee et al., 2013; Sessitsch et al., 2013). Sedum plumbizincicola is one of the hyperaccumulators (Jiang et al., 2010) which has a remarkable capacity to withstand the metal stress in polluted soils and recent experiments have also demonstrated its potential for heavy metal phytoextraction (Wu et al., 2008). Although there is much interest in increasing the phytoremediation efficiency of S. plumbizincicola, effects of interactions of metal mobilizing microbes and $S$. plumbizincicola on the heavy metal phytoremediation, to our knowledge, has not been investigated. The objectives of our study were to isolate and characterize metal mobilizing PGPR from the rhizosphere of $S$. plumbizincicola and to investigate the effects of metal mobilizing PGPR on plant growth and $\mathrm{Cd}, \mathrm{Zn}$ and $\mathrm{Pb}$ uptake by S. plumbizincicola in multi-metal contaminated soils.

\section{Materials and methods}

\subsection{Isolation of metal tolerant bacterial strain}

The bacterial strains were isolated from rhizosphere of S. plumbizincicola grown on $\mathrm{Pb} / \mathrm{Zn}$ mine spoils in Chunan city of Zhejiang, Southeast of China. The physicochemical properties of soil were determined according to standard methods. The selected characteristics of the soil were: $\mathrm{pH}(1: 1 \mathrm{w} / \mathrm{v}$ water $) 7.6$; organic matter $1.36 \%$; copper $1.83 \mathrm{~g} \mathrm{~kg}^{-1}$; zinc $0.992 \mathrm{~g} \mathrm{~kg}^{-1}$; cadmium $0.0913 \mathrm{~g} \mathrm{~kg}^{-1}$; lead $14.2 \mathrm{~g} \mathrm{~kg}^{-1}$. About $1 \mathrm{~g}$ of soil samples were serially diluted using $25 \mathrm{mM}$ phosphate buffer and spread over on sucrose minimal salts low-phosphate (SLP) medium amended with $100 \mathrm{mg} \mathrm{L}^{-1}$ of $\mathrm{Cd}\left(\mathrm{CdCl}_{2}\right)$, $\mathrm{Zn}\left(\mathrm{ZnSO}_{4}\right)$, or $\mathrm{Pb}\left(\mathrm{Pb}\left(\mathrm{NO}_{3}\right)_{2}\right)$. This medium was designed to avoid metal salt precipitation (Sheng et al., 2008). The plates were incubated at $37^{\circ} \mathrm{C}$ for $48 \mathrm{~h}$. From the metal-resistant colonies, different strains were picked and purified on the SLP agar medium containing $100 \mathrm{mg}_{\text {metal }} \mathrm{L}^{-1}$. In order to isolate an effective metal mobilizing bacterial strain, the metal resistant isolates were tested for their ability to increase the water soluble $\mathrm{Cd}, \mathrm{Zn}$ and $\mathrm{Pb}$ concentrations in soils. The metal contaminated soils were collected from Fuyang city of Zhejiang province, PR China, sieved and sterilized by steaming $\left(100^{\circ} \mathrm{C}\right.$ for $1 \mathrm{~h}$ on three consecutive days) (Table 1 ). The metal resistant strains were grownin Luria-Bertani (LB) broth and placed on a shaker at $200 \mathrm{rpm}$ and $27^{\circ} \mathrm{C}$. After $24 \mathrm{~h}$, optical density (OD) was measured at $600 \mathrm{~nm}$ and adjusted to 1.5 ; the cultures were centrifuged at $6000 \mathrm{rpm}$ for $10 \mathrm{~min}$, washed in phosphate buffer ( $\mathrm{pH} 7.0)$ and resuspended in sterile water. The bacterial cultures (up to $1 \mathrm{~mL}$ ) were added to the $1 \mathrm{~g}$ of sterile metal contaminated soils in the centrifuge tubes. Sterile water was used as the control. All tubes were weighed, wrapped in brown paper and kept on an orbital shaker at $200 \mathrm{rpm}$ and $27^{\circ} \mathrm{C}$. The tubes were again weighed after $7 \mathrm{~d}$ to compensate for water-evaporation. To extract the soil water-soluble metal, $10 \mathrm{~mL}$ of sterile water was added to each tube (Rajkumar et al., 2008). The soil suspensions were centrifuged at $7000 \mathrm{rpm}$ for $10 \mathrm{~min}$ and filtered. The concentrations of metals in the filtrate were determined using an atomic absorption spectrophotometer.

\subsection{Characterization of metal mobilizing strain}

\subsubsection{Genetic characterization}

The bacterial strain was grown in LB broth at $30^{\circ} \mathrm{C}$ and total DNA was extracted using the QuickExtract bacterial DNA extraction kit. The 16S rRNA was amplified using the following primers FAM27f (5'-GAGTTTGATCMTGGCTCAG-3') and 1492r (5'GGYTACCTTGTTACGACTT-3'). Each amplification mixture $(5 \mu \mathrm{L})$ was analyzed by agarose gel $(1.5 \%, \mathrm{w} / \mathrm{v})$ electrophoresis in TAE buffer (0.04 M Tris acetate, 0.001 MEDTA) containing $1 \mu \mathrm{g} \mathrm{mL} \mathrm{L}^{-1}(\mathrm{w} / \mathrm{v})$ ethidium bromide. Partial nucleotide sequence of the amplified 16S rDNA was determined using automated DNA sequencer, and then compared to similar sequences in the GenBank using the BLAST analysis.

\subsubsection{Heavy metal resistance levels}

To check the metal resistant levels, the selected bacterial strain was grown in LB agar media containing different concentrations of $\mathrm{Cd}, \mathrm{Zn}$ or $\mathrm{Pb}$ ranging from 100 to $1200 \mathrm{mg} \mathrm{L}^{-1}$. Cultures were incubated at $27{ }^{\circ} \mathrm{C}$ for $7 \mathrm{~d}$. The highest concentration of metal supporting growth was defined as the maximum resistance level. Moreover, the growth pattern of the isolated bacterial strain in metal contaminated liquid medium was also determined.Briefly, the $250 \mathrm{~mL}$ culture flask containing $20 \mathrm{~mL}$ LB broth supplemented with heavy metals at the concentration of $200 \mathrm{mg} \mathrm{L}^{-1}$ (Cd, $\mathrm{Zn}$ or $\mathrm{Pb}$ ) were inoculated with logarithmic-phase bacterial isolate. All

Table 1

The physiochemical properties of soils used in metal mobilization and pot experiments.

\begin{tabular}{lc}
\hline Soil property & Value \\
\hline $\mathrm{pH}\left(\mathrm{H}_{2} \mathrm{O}\right)$ & 8.1 \\
Cation exchange capacity $\left(\mathrm{cmol} \mathrm{kg}^{-1}\right)$ & $11.4 \pm 0.1$ \\
Organic matter $\left(\mathrm{g} \mathrm{kg}^{-1}\right)$ & $36.3 \pm 1.2$ \\
Total element concentration & \\
$\mathrm{N}\left(\mathrm{g} \mathrm{kg}^{-1}\right)$ & $1.7 \pm 0.0$ \\
$\mathrm{P}\left(\mathrm{g} \mathrm{kg}^{-1}\right)$ & $1.1 \pm 0.1$ \\
$\mathrm{~K}\left(\mathrm{~g} \mathrm{~kg}^{-1}\right)$ & $18.6 \pm 0.2$ \\
$\mathrm{Cd}\left(\mathrm{mg} \mathrm{kg}^{-1}\right)$ & $5.9 \pm 0.3$ \\
$\mathrm{Zn}\left(\mathrm{mg} \mathrm{kg}^{-1}\right)$ & $36 \pm 13$ \\
$\mathrm{~Pb}\left(\mathrm{mg} \mathrm{kg}^{-1}\right)$ & $153 \pm 8$ \\
Extractable element concentration $\left(1 \mathrm{M} \mathrm{NH}_{4} \mathrm{NO}_{3}\right)$ & \\
$\mathrm{N}\left(\mathrm{mg} \mathrm{kg}^{-1}\right)$ & $107 \pm 1$ \\
$\mathrm{P}\left(\mathrm{mg} \mathrm{kg}^{-1}\right)$ & $9.4 \pm 1.3$ \\
$\mathrm{~K}\left(\mathrm{mg} \mathrm{kg}^{-1}\right)$ & $60.7 \pm 0.8$ \\
\hline
\end{tabular}

Values represent means $\pm \operatorname{SD}(n=5)$. 
the cultures including controls (in triplicate) were incubated at $27{ }^{\circ} \mathrm{C}$ for $36 \mathrm{~h}$ at $200 \mathrm{rpm}$. The bacterial growth was measured once in every $4 \mathrm{~h}$ by measuring the OD at $600 \mathrm{~nm}$.

\subsubsection{Characterization of plant growth promoting features}

The metal mobilizing isolate was screened for the ability to grow on Dworkin-Foster (DF) salts minimal medium (Dworkin and Foster, 1958) with ACC as the sole nitrogen source. The inoculated DF salt minimal medium without ACC was used as a blank. The bacterial growth was monitored by measuring the OD at $600 \mathrm{~nm}$. Further, the ACC deaminase activity was determined as described by Ma et al. (2009). Siderophore production by metal mobilizing strain was detected by the method of Schwyn and Neilands (1987) using chrome azurol S (CAS) agar. The diameters of orange halo produced by the colony on blue agar were indicative of the siderophore biosynthesis level. The presence of catechol and hydroxamate siderophores in iron-restricted bacterial culture supernatants was also quantitatively determined by the calorimetric assay of Arnow (1937) and Atkin et al. (1970) method, respectively.

The metal mobilizing isolate was further analyzed for its ability to solubilize insoluble $\mathrm{P}$ using modified Pikovskayas medium (Sundara-Rao and Sinha, 1963). The soluble phosphate in the culture supernatant was quantified as described by Park et al. (2011). Production of indole-3-acetic acid (IAA) by metal mobilizing isolate was assayed as described by Bric et al. (1991) using LB medium with different concentrations of L-tryptophan $(0,1,2$, 3, 4 and $5 \mathrm{mg} \mathrm{mL}^{-1}$ ).

\subsection{Pot experiment}

For pot experiments, the soils samples collected from Fuyang city of Zhejiang Province, PR China were dried and passed through a $2 \mathrm{~mm}$ sieve (Table 1). The plants, S. plumbizincicola were obtained from an old $\mathrm{Pb} / \mathrm{Zn}$ mine in Chunan city of Zhejiang province, China. The fresh shoot samples (approximately $5 \mathrm{~cm}$ long with a pair of leaves and 4-5 nodes) were cleaned with tap water and grown in a half-strength Hoagland's nutrient solution for $7 \mathrm{~d}$. Roots of precultured seedlings were surface-sterilized by sequential immersion in $70 \%(\mathrm{v} / \mathrm{v})$ ethanol for $1 \mathrm{~min}$, and $3 \% \mathrm{NaClO}$ for $3 \mathrm{~min}$ and washed several times with sterile water. For inoculation of the seedlings, the overnight grown bacterial culture was centrifuged at $6000 \mathrm{rpm}$ for $10 \mathrm{~min}$ and the pellet was washed twice with biological saline $(0.85 \% \mathrm{KCl})$. The pellet was resuspended in biological saline and the $\mathrm{OD}_{600}$ was adjusted to 1.5 . The roots of seedlings were soaked for $2 \mathrm{~h}$ in the bacterial culture or sterile water (controls) and transplanted in plastic pot containing $750 \mathrm{~g}$ of metal polluted soil (six plants pot $^{-1}$ ). The plant seedlings were allowed to grow in a greenhouse at $25 \pm 5^{\circ} \mathrm{C}$ and a $16: 8 \mathrm{~d} /$ night regime. Each treatment was performed in five replicates. After $75 \mathrm{~d}$, the plants were carefully removed from the pots and the root surface was cleaned several times with distilled water. Plant root and shoot length, fresh and dry weight were measured, respectively. The accumulation of metals $(\mathrm{Cd}, \mathrm{Zn}$, and $\mathrm{Pb})$ in root and shoot system was quantified as described by Ma et al. (2009).

\subsection{Statistical analysis}

Analysis of variance followed by post hoc Fisher Least Significant Difference test $(p<0.05)$ were used to compare treatment means. All the statistical analyses were carried out using SPSS 10.0.

\section{Results and discussion}

\subsection{Isolation of metal mobilizing bacteria}

Effective microbe-assisted phytoextraction depends on the identification of metal resistant PGPR capable of improving the plant growth and bioavailability of heavy metals in soils and the selection of suitable plants with potential to tolerate and uptake high concentrations of heavy metals. It has been previously reported by several authors that the inoculation of plants with PGPR, could improve the plant survival in metal polluted soils due to the microbial activity/action in the rhizosphere soils (Prapagdee et al., 2013; Srivastava et al., 2013). In particular, the efficiency of heavy metal extraction by hyperaccumulators can be enhanced by inoculating metal mobilizing PGPR. In this study, the metal mobilizing bacteria were isolated from the rhizosphere of $S$. plumbizincicola grown on $\mathrm{Pb} / \mathrm{Zn}$ mine spoils with an objective to assess the interactive effects of $S$. plumbizincicola and metal mobilizing bacteria on heavy metal phytoremediation. During the initial screening process, a total of 45 morphologically different metal-resistant bacterial strains were isolated. Out of the 45 isolates, strain RC6b was specifically chosen for further studies due to its high metal solubilization ability in soil (Fig. 1). Compared with non-inoculated control treatment,inoculation of RC6b for $7 \mathrm{~d}$, significantly increased the concentrations of water soluble $\mathrm{Cd}, \mathrm{Zn}$ and $\mathrm{Pb}$ in soil by 16.7, 4.6- and 5.7-fold, respectively. These results are consistent with those of Jiang et al. (2008) and Rajkumar et al. (2008) and Ma et al. (2009), they found an increase in metal concentrations ( $\mathrm{Ni}$, $\mathrm{Cu}, \mathrm{Zn}, \mathrm{Cd}$ and $\mathrm{Pb}$ ) in water soluble fractions in the presence of metal mobilizing bacteria. The observed increase in the concentrations of water soluble metals in this study could be attributed to the effects of microbial metabolites/actions such as altering soil $\mathrm{pH}$, release of organic acids, siderophores and oxidation/reduction reactions (Rajkumar et al., 2012, 2013).

\subsection{Characterization of metal mobilizing $R C 6 b$}

\subsubsection{Genetic characterization}

The bacterial strain that showed the highest metal solubilization capacity, RC6b was identified as Phyllobacterium myrsinacearum based on the highest sequence similarity (99\%) and phylogeny analysis. The obtained sequence (1359 bp) was deposited in the GenBank with accession number JX512224. Phylogenetic tree in

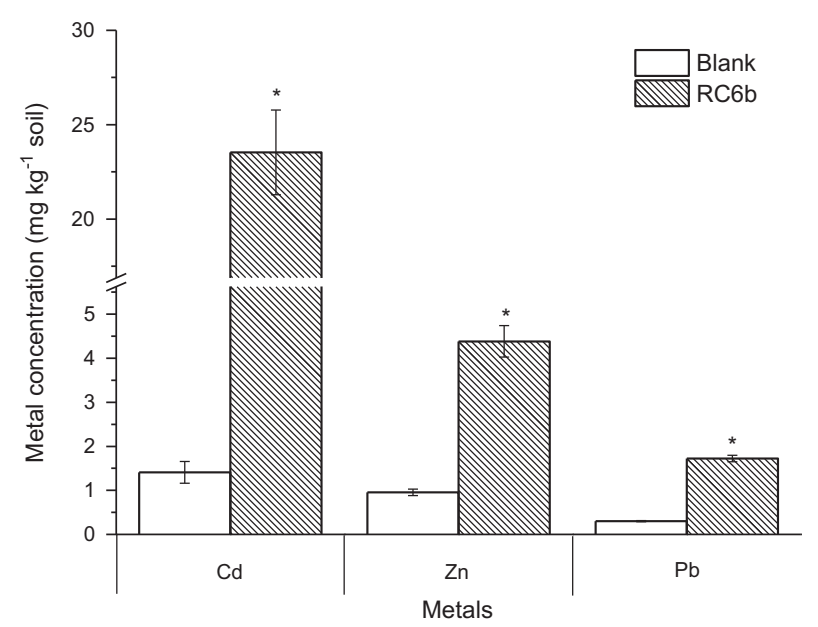

Fig. 1. Effect of inoculation with P. myrsinacearum RC6b on the solubilization of Cd $\mathrm{Zn}$ and $\mathrm{Pb}$ in soil. Bars represent standard deviations of three replicates. An asterisk $\left({ }^{*}\right)$ denotes a value significantly greater than the corresponding control value according to Fisher's protected LSD test $(p<0.05)$. 
Fig. 2 based on 16S rRNA sequence revealed a relationship between isolated strain in this research and other related bacteria reported in the literature.

\subsubsection{Heavy metal resistance levels}

The microorganisms isolated from metal contaminated natural environment can be constitutively or adaptatively resistant to increasing metal concentrations and various strategies including physical sequestration, exclusion, complexation and detoxification can be developed by adapted strain to resist high metal concentrations (Nies, 2003). In this study, the strain P. myrsinacearum RC6b was found to exhibit multiple heavy metal resistance characteristics. The strain RC6b showed resistance against $350 \mathrm{mg} \mathrm{Cd} \mathrm{L}^{-1}$, $1000 \mathrm{mg} \mathrm{Zn} \mathrm{L}^{-1}$ and $1200 \mathrm{mg} \mathrm{Pb} \mathrm{L}^{-1}$. Among the heavy metals, $\mathrm{Pb}$ and $\mathrm{Zn}$ were less toxic, whereas $\mathrm{Cd}$ were highly toxic to strain RC6b with the order ofresistance is $\mathrm{Pb}>\mathrm{Zn}>\mathrm{Cd}$. For more information on the behavior of the microbial strains in metal contaminated liquid medium and the capacity of the strains to survive and grow in unfavorable conditions, the growth rate of RC6b in the presence of heavy metals was also determined. The growth pattern of RC6b exhibited a variation in control compared to that of the metals used (Fig. 3a). During the initial $20 \mathrm{~h}$, the maximum growth was observed in control followed by that exposed to $200 \mathrm{mg} \mathrm{Pb} \mathrm{L}^{-1}$. Although a slight decrease in the overall growth of RC6b in the presence of metals was evident during the initial $12 \mathrm{~h}$, the bacterial cells were able to return to normal growth under all conditions tested after $16 \mathrm{~h}$.Similar results were also reported for other metal resistant rhizobacteria e.g., Bacillus thuringiensis OSM29, Agrobacterium tumefaciens LMG196 (Wei et al., 2009; Oves et al., 2013) indicating that the bacterial strains isolated from metal polluted soils have adapted to multiple heavy metal stress by developing various mechanisms.

\subsubsection{Plant growth promoting traits of $P$. myrsinacearum $R C 6 b$}

The plant associated bacteria isolated from metal contaminated rhizosphere soils that are known to improve the plant growth in the presence of heavy metals have various plant growth promoting traits such as production of ACC deaminase, IAA, siderophores and/ or solubilization of $\mathrm{P}$, which are the implicated mechanisms that contribute to the reduced metal stress and increased growth in their host plants (Ma et al., 2011; Rajkumar et al., 2012).

Production of ACC deaminase by PGPR is one of the key traits that attenuate ethylene-mediated plant growth inhibition through metabolizing the ethylene precursor, ACC into $\alpha$-ketobutyrate $(\alpha-K B)$ and ammonia (Glick et al., 2007). In this study, the metal mobilizing strain RC6b was initially tested for its ability to grow on DF salts minimal medium with or without ACC. The strain RC6b grew well in DF salts minimal medium with ACC, whereas, in the absence of ACC it showed a limited growth (Fig. 3b). These observations indicate that RC6b has the potential to utilize ACC as a sole source of nitrogen through producing an enzyme ACC deaminase. Further, the ACC deaminase activity of RC6b was
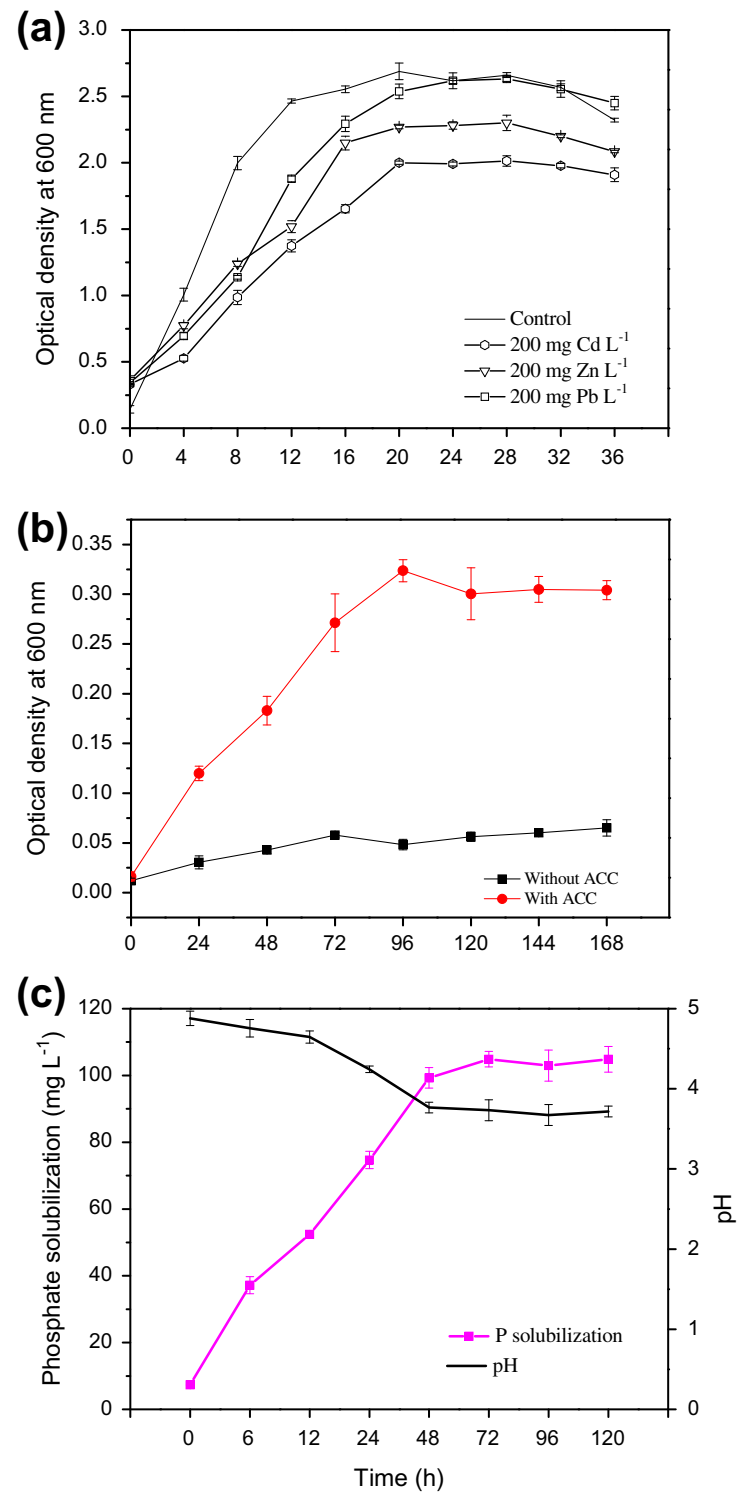

Fig. 3. Growth pattern of $P$. myrsinacearum RC6b in LB medium supplemented with metals at the concentrations of $200 \mathrm{mg} \mathrm{L}^{-1}$ (a). Growth of RC6b on DF salts minimal medium (b). Phosphate solubilization by RC6b (c). The amount of soluble phosphates released was determined from the absorbance data using the calibration curve of $\mathrm{KH}_{2} \mathrm{PO}_{4}$ at $880 \mathrm{~nm}$. Bars represent standard deviations of three replicates.

analyzed by quantifying theamount of $\alpha$-KB produced. The isolate produced $15.2 \mu \mathrm{mol} \alpha-\mathrm{KB} \mathrm{mg}^{-1}$ protein $\mathrm{h}^{-1}$, which confirmed the enzyme activity.

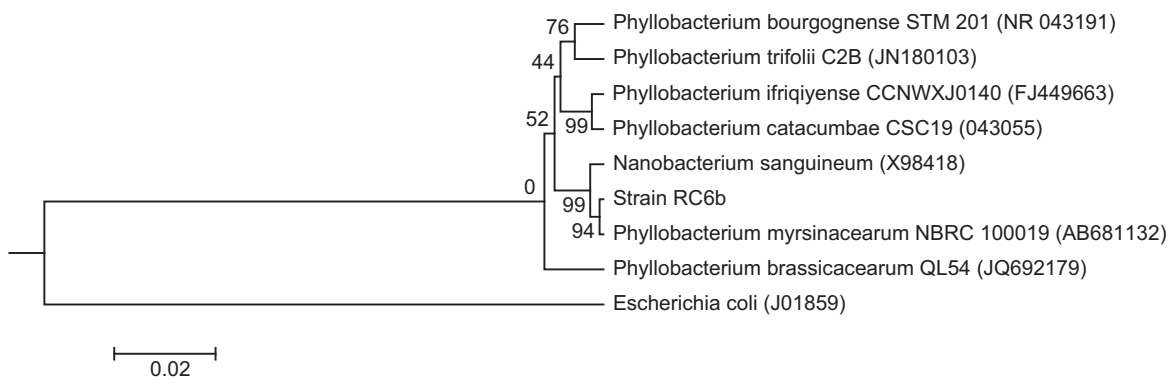

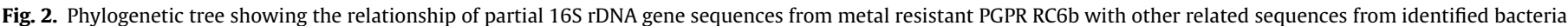

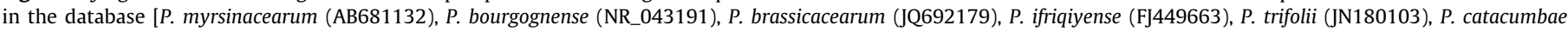
(NR_043055), Nanobacterium sanguineum (X98418) and Escherichia coli (J01859)]. E. coli was used as the out-group. The bar represents 0.02 substitutions per site. 
Siderophore production by metal resistant PGPR is an important biological process, making iron available to plants in metal polluted soil environment (Rajkumar et al., 2012). In this study, the production of siderophores by RC6b was analyzed using CAS method. Strain RC6b exhibited positive reactions for siderophore production by forming orange-colored zone on CAS agar plates. Further the types of siderophores were also determined by the colorimetric method of Arnow (1937), using 2,3-dihydroxybenzoic acid and the Atkin et al. (1970) assay, using desferrioxaminemesylate as standards, where RC6b shown the ability to produce both catechol $\left(654 \mathrm{mg} \mathrm{L}^{-1}\right)$ and hydroxamate $\left(83.9 \mathrm{mg} \mathrm{L}^{-1}\right)$ type siderophores.

It has been well established that, as a common strategy to scavenge $P$ from insoluble mineral sources, microorganisms produce and exudate various organic acids (Rajkumar et al., 2012). The phosphate solubilization potential of RC6b was studied over a time period of $120 \mathrm{~h}$ by monitoring $\mathrm{pH}$ drop and available phosphorus in the culture medium. Maximum phosphate solubilization, that is, $105 \mathrm{mg}$ of $\mathrm{P} \mathrm{mg} \mathrm{L}^{-1}$ was detected after $72 \mathrm{~h}$ incubation along with a significant $\mathrm{pH}$ decrease from 4.88 to 3.73 (Fig. 3c). These results indicate that acidification seemed to be the main strategy followed by RC6b for solubilizing P. A recent study on the influence of phosphobacteria isolated from the rhizosphere of Coffea arabica L. on solubilizing insoluble hydroxyapatite/tricalcium phosphate also revealed that the solubilization of $\mathrm{P}$ compounds strongly depended on the release of various organic acids such as 2-ketogluconic, gluconic acids and acetic acid (Muleta et al., 2013). It has been reported that the plant associated microbes in metal polluted rhizosphere soils may mobilize insoluble phosphates very efficiently as a consequence of the production of various organic acids, which results in decrease in the metal-induced $P$ deficiency in plants (Park et al., 2011; Muleta et al., 2013).

As it is well documented that the production of IAA by plant associatedbacteria in the rhizosphere greatly contributes to the plant growth in metal polluted soils through stimulating plant root growth and the ability to take up water and nutrients, the potential of $P$. myrsinacearum RC6b to produce IAA was determined. As shown in Fig. 4a, the production of IAA by RC6b in LB medium supplemented with L-tryptophan $\left(1 \mathrm{mg} \mathrm{mL}^{-1}\right)$ exhibited a maximum IAA accumulation ( $\left.96.5 \mathrm{mg} \mathrm{L}^{-1}\right)$ at $72 \mathrm{~h}$ of incubation; thereafter, it was decreased and maintained constant for a period of time. This decrease was probably attributed to the release of IAA degrading enzymes such as IAA oxidase and peroxidase (Datta and Basu, 2000). Since root borne nutrients particularly L-tryptophan are considered as an important components for bacterial IAA production as well as for their growth in the rhizosphere, the strain RC6b was further tested for its ability to produce IAA in culture media supplemented with various concentrations of L-tryptophan. As shown in Fig. 4b, RC6b did not produce IAA in the absence of tryptophan in the growth medium whereas in the presence of $2 \mathrm{mg} \mathrm{mL}^{-1}$ tryptophan, it produced maximum amounts of IAA. However, a noticeable decrease in IAA production was observed at higher concentrations of L-tryptophan $\left(3,4\right.$ and $\left.5 \mathrm{mg} \mathrm{mL}^{-1}\right)$. These results concur with the earlier observations Khamna et al. (2010) indicating that L-tryptophan at higher concentration exerts negative effects on IAA production. On the other side, some recent studies found strong linear correlation between the bacterial IAA production and L-tryptophan concentrations in the growth media (Legault et al., 2011; Patil, 2011). These contradictions require further studies to be clearly explained.

Efficient heavy metal-mobilizing abilities and the potential to grow under multi-metal stress conditions along with various plant beneficial traits are clear indications of the advantages that may offer to employ this organism as an inoculant for improving the efficiency of heavy metal phytoremediation. Similar to our findings of multiple plant growth promoting traits in metal resistant PGPR have been reported by some other workers (Sheng et al.,2008; Srivastava et al., 2013), while such findings on metal mobilizing rhizosphere isolates are less commonly explored.

\subsection{Influence of P. myrsinacearum RC6b on plant growth and metal uptake}

The positive effects of PGPR inoculation on heavy metal phytoremediation may be attributed to either the effect of microbial metabolites on improving plant growth or increasing plant metal uptake, or a combination of both mechanisms. In general, heavy metals in plants especially $\mathrm{Cd}$ even at lower concentrations, may inhibit plant growth and yield through affecting various physiological and biochemical processes (Sanita di Toppi and Gabbrielli, 1999). In our study, S. plumbizincicola inoculated with RC6b performed better in terms of growth in metal polluted soils (Table 2). The strain RC6b increased the root length, shoots length, fresh weight and dry weight by $176 \%, 27 \%, 27 \%$ and $22 \%$, respectively, compared to non-inoculated plants. The increase in plant growth caused by $P$. myrsinacearum RC6b in metal contaminated soils may be attributed to its ability to produce IAA, ACC deaminase, siderophores and solubilize P (Prapagdee et al., 2013; Srivastava et al., 2013). It has been reported that PGPR (e.g., Bacillus weihenstephanensis, Pseudomonas chlororaphis, Microbacterium lactium, Microbacterium sp., Micrococcus sp., and Klebsiella sp.) isolated from metal polluted soils may help plants to produce more biomass by providing the plant with IAA that directly stimulates plant cell elongation, cell division, root initiation, and/or expression of specific genes (Prapagdee et al., 2013). Further, several plant associated bacteria were found to possess ACC deaminase suggesting their possible role in decreasing the amount of ACC as well as ethylene in the roots, thereby reducing heavy metal induced damages in plants (Glick et al., 2007). Similarly, recent studies have also indicated that under heavy metal stress conditions, inoculation with PGPR possessing the ability to produce siderophores and solubilize P increased growth of the inoculated plants primarily through enhancing the nutrient uptake in the inoculated plants (Ma et al., 2010). Our results show that RC6b can produce ACC deaminase, siderophores, IAA and solubilize $\mathrm{P}$ that can improve the plant growth in metalpolluted soils through exhibiting individual or combined effects of plant growth promoting metabolites. Further work is under progress to elucidate the exact mechanisms that are essential to plant growth promoting potential of RC6b.

The alterations in heavy metal mobilization and its solubility in the rhizosphere soils caused by chemical and/or biological features can have dramatic effect on heavy metal uptake/accumulation in plants (Sessitsch et al., 2013). In this study thus the effects of metal mobilizing RC6b on metal accumulation in roots and shoots of $S$. plumbizincicola were studied. In general, inoculation of RC6b significantly increased the accumulation of $\mathrm{Cd}$ and $\mathrm{Zn}$ in root and shoot system (Table 2). For instance, RC6b increased $\mathrm{Cd}$ and $\mathrm{Zn}$ concentration in the shoot tissues by $57 \%$ and $34 \%$, respectively. This corroboratesthe data shown in Fig. 1 for bacterial metal solubilization indicating that inoculation with metal mobilizing RC6b facilitated $\mathrm{Cd}$ and $\mathrm{Zn}$ solubilization in the rhizosphere soils and thereby enhanced their uptake by plants. Previously, Ghosh et al. (2011) also reported that the increase in arsenic bioavailability after PGPR (Pseudomonas sp., Comamonas sp., and Stenotrophomonas sp.) inoculation could enhance the arsenic uptake of hyperaccumulator plant Pteris vittata L. Prapagdee et al. (2013) also found that the inoculation of PGPR, Micrococcus sp. MU1 and Klebsiella sp. BAM1 increased Cd solubility in soils and thereby improving the phytoextraction efficiency of Helianthus annuus in metal polluted soils. However, in the case of $\mathrm{Pb}, \mathrm{RC} 6 \mathrm{~b}$ inoculation decreased metal accumulation in root (85\%) and shoot (95\%) systems of S. plumbizincicola plants (Table 2) although RC6b showed $\mathrm{Pb}$ solubilization 


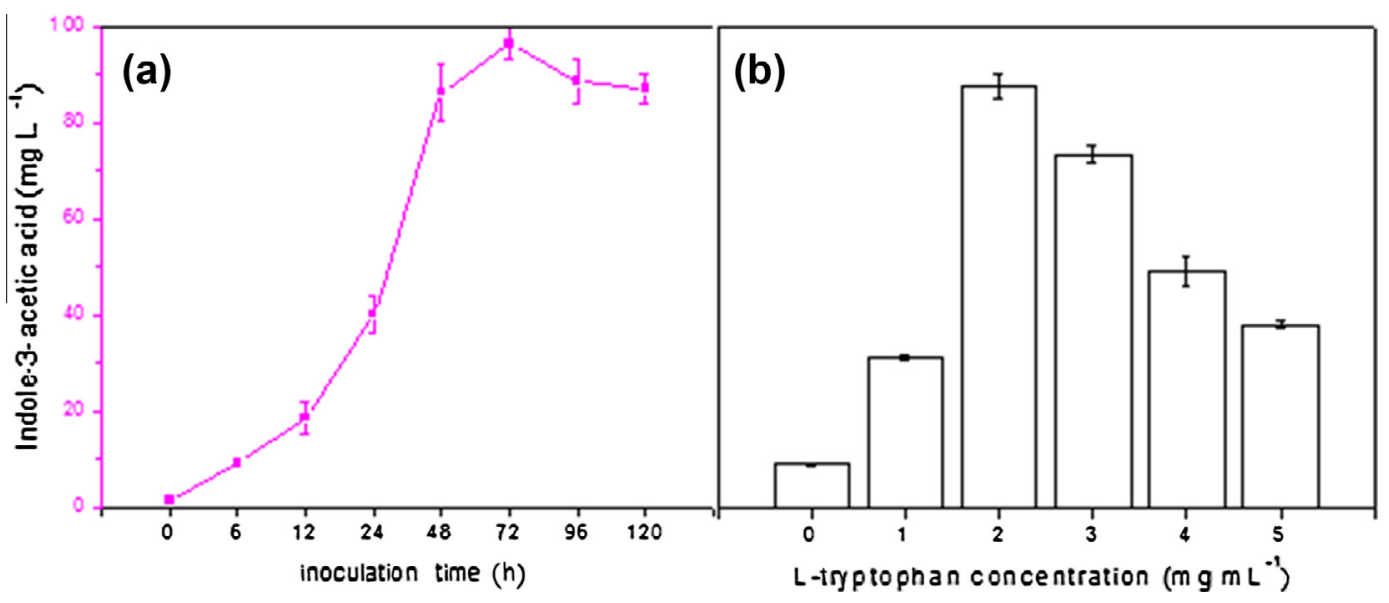

Fig. 4. Effect of inoculation time (a) and L-tryptophan concentration (b) on IAA production of RC6b. Bars represent standard deviations of three replicates.

Table 2

Influence of $P$. myrsinacearum RC6b on the plant growth and the uptake ( $\mathrm{mg} \mathrm{kg}^{-1}$ ) of $\mathrm{Cd}, \mathrm{Zn}$ and $\mathrm{Pb}$ by S. plumbizincicola.

\begin{tabular}{|c|c|c|c|c|c|c|c|c|c|c|}
\hline \multirow[t]{2}{*}{ Treatment } & \multirow{2}{*}{$\begin{array}{l}\text { Root length } \\
(\mathrm{cm})\end{array}$} & \multirow{2}{*}{$\begin{array}{l}\text { Shoot length } \\
(\mathrm{cm})\end{array}$} & \multirow{2}{*}{$\begin{array}{l}\text { Fresh weight } \\
\left(\mathrm{g} \mathrm{plant}^{-1}\right)\end{array}$} & \multirow{2}{*}{$\begin{array}{l}\text { Dry weight } \\
\text { (g plant }^{-1} \text { ) }\end{array}$} & \multicolumn{2}{|c|}{ Cd concentration } & \multicolumn{2}{|c|}{ Zn concentration } & \multicolumn{2}{|c|}{ Pb concentration } \\
\hline & & & & & Root & Shoot & Root & Shoot & Root & Shoot \\
\hline Control & $4.6 \pm 0.3$ & $17.2 \pm 1.2$ & $46 \pm 2$ & $4 \pm 0$ & $35 \pm 6$ & $93 \pm 4$ & $889 \pm 57$ & $1072 \pm 38$ & $99 \pm 11$ & $101 \pm 11$ \\
\hline RC6b & $12.8 \pm 4.2^{*}$ & $21.8 \pm 1.7^{*}$ & $58 \pm 9^{*}$ & $5 \pm 1$ & $47 \pm 5^{*}$ & $146 \pm 2^{*}$ & $1310 \pm 174^{*}$ & $1435 \pm 31^{*}$ & $15 \pm 0$ & $5 \pm 1$ \\
\hline
\end{tabular}

Average \pm standard deviation from five samples.

"A value significantly greater than the corresponding control value according to Fisher's protected LSD test $(p<0.05)$.

potential in metal solubilization experiments (Fig. 1). These effects of inoculation were also reported by Park and Bolan (2013), who found that the inoculation of plants with P-solubilizing bacteria decreased the concentration of shoot $\mathrm{Pb}$ in Brassica juncea in agar medium by $58.1 \%$ and in Lolium perenne in soil by $22.8 \%$ compared with respective non-inoculated control. This study showed that the $\mathrm{P}$-solubilizing bacteria facilitate $\mathrm{Pb}$ immobilization via the release of $\mathrm{P}$ from insoluble $\mathrm{P}$ compounds, thus making $\mathrm{Pb}$ (as a carbonatedfluoropyromorphite-like mineral) unavailable for plant uptake. However, Jeong et al. (2012) found that the inoculation of plants with P-solubilizing Bacillus megaterium increased the Cd concentration in B. juncea and Abutilon theophrasti by two folds compared with respective non-inoculated control. Taken together, present and previous research indicating that besides the bacterial metal solubilization activity, the other factors including soil nutrients level, $\mathrm{pH}$, type of metals, plants, etc., greatly influence the metal solubilization in soils and thereby alter its uptake by plants (Martínez-Alcalá et al., 2009; Rajkumar et al., 2013).

The efficiency of microbe-assisted phytoremediation is dependent on the survival and the competitiveness of the inoculants against nativepopulations. Although the colonization and survival efficiency of RC6b in the rhizosphere soils has not been studied in the present study, the improved plant growth and metal accumulation (especially Cd and $\mathrm{Zn}$ ) in plant tissues after RC6b inoculation clearly indicates its potential to tolerate, survive and express plant beneficial traits under metal stress conditions. To the best of our knowledge, this is the first work on the utilization of metal resistant PGPR RC6b as a metal mobilizer to induce phytoextraction potential of $S$. plumbizincicola in multi-metal contaminated soils.

\section{Conclusions}

Our work has demonstrated that metal mobilizing $P$. myrsinacearum RC6b isolated from the rhizosphere of hyperaccumulator $S$. plumbizincicola, is able to withstand high metal concentrationsand can exhibit multiple plant growth beneficial properties including production of siderophores, IAA, ACC deaminase and solubilization of $P$. The results further suggested that activities of $P$. myrsinacearum RC6b in the rhizosphere soils can significantly improve the phytoremediation potential of plants in metal polluted soils through increasing two factors that control this parameter, i.e., plant biomass production and its metal accumulation. Further investigations on this metal mobilizing P. myrsinacearum RC6b for its efficiency under field conditions are in progress to promote it as bioinoculant for improving the phytoremediation in metal polluted soils.

\section{Acknowledgments}

Y. Ma thankfully acknowledges the Portuguese Foundation for Science and Technology (FCT) for awarding a post-doctoral research grant (SFRH/BPD/76028/2011). M. Rajkumar acknowledges the financial support received in the form of Ramalingaswami re-entry fellowship from Department of Biotechnology (DBT), Government of India.

\section{References}

Arnow, E., 1937. Colorimetric determination of the components of 3,4dihydroxyphenylalanine-tyrosine mixtures. J. Biol. Chem. 118, 531-537.

Atkin, C.L., Neilands, J.B., Phaff, H.J., 1970. Rhodotorulic acid from species of Leucosporidium, Rhodosporidium, Rhodotorula, Sporidiobolus, and Sporobolomyces, and a new alanine-containing ferrichrome from Cryptococcus melibiosum. J.Bacteriol. 103, 722-733.

Bric, J.M., Bostock, R.M., Silversone, S.E., 1991. Rapid in situ assay for indole acetic acid production by bacteria immobilization on a nitrocellulose membrane. Appl. Environ. Microbiol. 57, 535-538.

Datta, C., Basu, P.S., 2000. Indole acetic acid production by a rhizobium species from root nodules of a leguminous shrub, Cajanus cajan. Microbiol. Res. 155, 123127.

Dworkin, M., Foster, J., 1958. Experiments with some microorganisms which utilize ethane and hydrogen. J. Bacteriol. 75, 592-601.

Ghosh, P., Rathinasabapathi, B., Ma, L.Q., 2011. Arsenic-resistant bacteria solubilized arsenic in the growth media and increased growth of arsenic hyperaccumulator Pteris vittata L. Bioresour. Technol. 102, 8756-8761. 
Giller, K.E., Witter, E., McGrath, S.P., 1998. Toxicity of heavy metals to microorganisms and microbial processes in agricultural soils: a review. Soil Biol. Biochem. 30, 1389-1414.

Glick, B.R., 2003. Phytoremediation: synergistic use of plants and bacteria to clean up the environment. Biotechnol. Adv. 21, 383-393.

Glick, B.R., Cheng, Z., Czarny, J., Duan, J., 2007. Promotion of plant growth by ACC deaminase-producing soil bacteria. Eur. J. Plant Pathol. 119, 329-339.

Jeong, S., Moon, H.S., Nam, K., Kim, J.Y., Kim, T.S., 2012. Application of phosphatesolubilizing bacteria for enhancing bioavailability and phytoextraction of cadmium (Cd) from pollutedsoil. Chemosphere 88, 204-210.

Jiang, C.Y., Sheng, X.F., Qian, M., Wang, Q.Y., 2008. Isolation and characterization of a heavy metal-resistant Burkholderia sp. from heavy metal-contaminated paddy field soil and its potential in promoting plant growth and heavy metal accumulation in metal pollutedsoil. Chemosphere 72, 157-164.

Jiang, J.P., Wu, L.H., Li, N., Luo, Y.M., Liu, L., Zhao, Q.G., Zhang, L., Christie, P., 2010. Effects of multiple heavy metal contamination and repeated phytoextraction by Sedum plumbizincicola on soil microbialproperties. Eur. J. Soil Biol. 46, 18-26.

Kachenko, A.G., Singh, B., 2006. Heavy metals contamination in vegetables grown in urban and metal smelter contaminated sites in Australia. Water Air Soil Pollut. 169, 101-123.

Khamna, S., Yokota, A., Peberdy, J.F., Lumyong, S., 2010. Indole-3-acetic acid production by Streptomyces sp. isolated from some Thai medicinal plant rhizosphere soils. EurAsian J. BioSci. 4, 23-32.

Legault, G.S., Lerat, S., Nicolas, P., Beaulieu, C., 2011. Tryptophan regulates thaxtomin A and indole-3-acetic acid production in Streptomyces scabiei and modifies its interactions with radishseedlings. Phytopathology 101, 1045-1051.

Li, Y., Wang, Y.B., Gou, X., Su, Y.B., Wang, G., 2006. Risk assessment of heavy metals in soils and vegetables around non-ferrous metals mining and smelting sties, Baiyin, China. J. Environ. Sci.(China) 18, 1124-1134.

Ma, Y., Rajkumar, M., Freitas, H., 2009. Improvement of plant growth and nickel uptake by nickel resistant-plant growth promoting bacteria. J. Hazard. Mater. 166, 1154-1161.

Ma, Y., Rajkumar, M., Vicente, J., Freitas, H., 2010. Inoculation of Ni-resistant plant growth promoting bacterium Psychrobacter sp. strain SRS8 for the improvement of nickel phytoextraction by energy crops. Int. J.Phytoremediat. $13,126-139$.

Ma, Y., Prasad, M.N.V., Rajkumar, M., Freitas, H., 2011. Plant growth promoting rhizobacteria and endophytes accelerate phytoremediation of metalliferous soils. Biotechnol. Adv. 29, 248-258.

Martínez-Alcalá, I., Clemente, R., Bernal, M.P., 2009. Metal availability and chemical properties in the rhizosphere of Lupinus albus L. growing in a high-metal calcareous soil. Water Air Soil Pollut. 201, 283-293.

MEPPRC (Ministry of Environmental Protection of the People's Republic of China), 2006. Report on the State of the Environment in China, Beijing, China (in Chinese).

Muleta, D., Assefa, F., Börjesson, E., Granhall, U., 2013. Phosphate-solubilising rhizobacteria associated with Coffea arabica L. in natural coffee forests of southwestern Ethiopia. J. Saudi Soc. Agric.Sci. 12, 73-84.

Nies, D.H., 2003. Efflux-mediated heavy metal resistance in prokaryotes. FEMS Microbiol. Rev. 27, 313-339.
Oves, M., Khan, M.S., Zaidi, A., 2013. Biosorption of heavy metals by Bacillus thuringiensis strain OSM29 originating from industrial effluent contaminated north Indian soil. Saudi J. Biol. Sci. 20, 121-129.

Park, J.H., Bolan, N., 2013. Lead immobilization and bioavailability in microbial and root interface. J. Hazard. Mater, <http://www.dx.doi.org/10.1016/j.jhazmat. 2013.02.010>.

Park, J.H., Bolan, N., Mallavarapu, M., Naidu, R., 2011. Isolation of phosphate solubilizing bacteria and their potential for lead immobilization in soil. J. Hazard. Mater. 185, 829-836.

Patil, V., 2011. Production of indole acetic acid by Azotobacter sp.. Recent Res. Sci. Technol. 3, 14-16.

Prapagdee, B., Chanprasert, M., Mongkolsuk, S., 2013. Bioaugmentation with cadmium-resistant plant growth-promoting rhizobacteria to assist cadmium phytoextraction by Helianthus annuus. Chemosphere, <http://www.dx.doi.org/ 10.1016/j.chemosphere.2013.01.082>.

Rajkumar, M., Ma, Y., Freitas, H., 2008. Characterization of metal-resistant plantgrowth promoting Bacillus weihenstephanensis isolated from serpentine soil in Portugal. J. Basic Microbiol. 48, 1-9.

Rajkumar, M., Sandhya, S., Prasad, M.N.V., Freitas, H., 2012. Perspectives of plantassociated microbes in heavy metal phytoremediation. Biotechnol. Adv. 30, 1562-1574.

Rajkumar, M., Prasad, M.N.V., Sandhya, S., Freitas, H., 2013. Climate change driven plant-metal-microbe interactions. Environ. Int. 53, 74-86.

Sanita di Toppi, L., Gabbrielli, R., 1999. Response to cadmium in higher plants. Environ. Exp. Bot. 41, 105-130.

Schwyn, B., Neilands, J.B., 1987. Universal chemical assay for the detection and determination of siderophores. Anal. Biochem. 160, 47-56.

Sessitsch, A., Kuffner, M., Kidd, P., Vangronsveld, J., Wenzel, W.W., Fallmann, K., Puschenreiter, M., 2013. The role of plant-associated bacteria in the mobilization and phytoextraction of trace elements in contaminatedsoils. Soil Biol. Biochem. 60, 182-194.

Sheng, X.F., He, L.Y., Wang, Q.Y., Ye, H.S., Jiang, C., 2008. Effects of inoculation of biosurfactant producing Bacillus sp. J119 on plant growth and cadmium uptake in a cadmium amended soil. J. Hazard.Mater. 155, 17-22.

Srivastava, S., Verma, P.C., Chaudhry, V., Singh, N., Abhilash, P.C., Kumar, K.V. Sharma, N., Singh, N., 2013. Influence of inoculation of arsenic-resistant Staphylococcus arlettae on growth and arsenic uptake in Brassica juncea (L.) Czern. Var. R-46. J. Hazard. Mater, <http://www.dx.doi.org/10.1016/ j.jhazmat.2012.08.019>.

Sundara-Rao, W.V.B., Sinha, M.K., 1963. Phosphate dissolving microorganisms in the soil and rhizosphere. Indian J. Agric. Sci. 33, 272-278.

Wei, G.H., Fan, L.M., Zhu, W.F., Fu, Y.Y., Yu, J.F., Tang, M., 2009. Isolation and characterization of the heavy metal resistant bacteria CCNWRS33-2 isolated from root nodule of Lespedeza cuneata in gold mine tailings in China. J. Hazard. Mater. 162, 50-56.

Wu, L.H., Li, N., Luo, Y.M., 2008. Phytoextraction of heavy metal contaminated soil by Sedum plumbizincicola under different agronomic strategies. In: Proc. 5th Int. Phytotech. Conf., Nanjing, China, pp. 49-50.

Zhuang, P., McBride, M.B., Xia, H., Li, N., Li, Z., 2009. Health risk from heavy metals via consumption of food crops in the vicinity of Dabaoshan mine, South China. Sci. TotalEnviron. 407, 1551-1561. 